\title{
CAPITALIZING ON LEAD IN STAGE TO NURTURE CRITICAL THINKING: AN ATTEMPT TO COMBAT FAKE NEWS FOR SCREENAGERS
}

\author{
Rini Silvana \\ Madrasah Aliyah Negeri 1 Kota Tangerang, Indonesia \\ email: resilvan@gmail.com
}

\begin{abstract}
The study aims at improving critical thinking skill of screenagers - students who frequently face their smartphone screens - to be more critical consumers of information in the Internet era. Using a 10-minute critical thinking activities during the lead in stage as the action, the research explores how integrating critical thinking and problem solving in daily classroom activities help nurture students to be critical in the information coming to their social media accounts. To achieve the objectives, a classroom action research involving cycles of Planning, Acting, Observing, and Reflecting was conducted in an Islamic-based higher secondary school in Tangerang, Banten. This research utilized a teacher's journal, a questionnaire, and an interview guide for eliciting data. The data were analyzed descriptively and the results showed that students' critical thinking skill improved from cycle 1 to cycle 2. Results from questionnaire showed that students could differentiate fact and opinion as well as analyze information on their screens. A focus-group interview supported students' improvement on critical thinking skill highlighting that their ability to distinguish valid or fake information improved gradually. The study recommends that teacher and school policy makers shoud conduct intentional activity that can support students think critically.
\end{abstract}

Keywords: critical thinking skill, critical thinking activities, fake news, acyion research

\begin{abstract}
Abstrak
Penelitian ini bertujuan untuk meningkatkan keterampilan berpikir kritis para screenager (siswa yangsering menghadapi layar smartphone) menjadi konsumen informasi yang lebih kritis di era internet. Penelitian ini mengeksplorasi bagaimana mengintegrasikan pemikiran kritis dan pemecahan masalah dalam kegiatan kelas sehari-hari agar membantu siswa untuk menjadi kritis dalam menyikapi informasi yang masuk ke akun media sosial mereka. Untuk mencapai tujuan tersebut, telah dilakukan penelitian tindakan kelas yang meliputi siklus perencanaan, tindakan, pengamatan, dan refleksi di sebuah MAN 1 Tangerang, Banten. Penelitian ini menggunakan jurnal guru, angket, dan pedoman wawancara untuk memperoleh data. Analisis data dilakukan secara deskriptif dan hasil penelitian menunjukkan bahwa keterampilan berpikir kritis siswa meningkat dari siklus 1 ke siklus 2. Hasil angket menunjukkan bahwa siswa dapat membedakan fakta dan opini serta menganalisis informasi di layar monitor. Selain itu FGD telah mendukung peningkatan keterampilan berpikir kritis siswa untuk membedakan informasi yang valid atau palsu secara bertahap. Oleh karena tu kegiatan inovatif yang melibatkan guru, siswa, dan pembuat kebijakan untuk peningkatan keterampilan berpikir kritis harus didorong dan dibiasakan.
\end{abstract}

Kata Kunci: kemampuan berpikitr kritis, berita bohong, kegiatan belajar kritis, penelitian tindakan 


\section{INTRODUCTION}

Teenagers and their smartphones are inseparable. The arrival of the smartphone has changed almost every aspect of teenagers' lives, from the nature of their social interactions to their mental health. Teens are now on their phones when they wake up, throughout the day, and into the night. A simple survey conducted in the class in which this research is conducted shows that $100 \%$ of students own smartphones. Out of 40, 23 students or $57.5 \%$ access their smartphones 4-5 during school days. The rest varied from 3-4 hours $(27.5 \%)$ to $2-3$ hours $(15 \%)$. They admit that during weekends they have a 24-hour access to their smartphones. Their favorite media are WhatsApp, Instagram, Webtoon, and Youtube.

WhatsApps, as one of students' favorite messaging platform, is one of social media that facilitates effective and timely communication online. It is a free cross- platform application that can be used in most smartphones and, as such, no additional equipment is required. The application is simple to use and is capable of sending multimedia messages, such as images, videos, and files as attachments, with ease.

The trend with WhatsApp makes teenagers have instantaneous access to information, which is unfortunately, not all valid, it can even contain fake news, misinformation and propaganda. Funke (2017) states that most of the fake news seen on WhatsApp seems it was picked up online and re-shared on the app, rather than created on the platform. Moreover, WhataApp is more compartmentalized, it is hard for factchekers, as in Facebook and Twitter, when and where fake news goes viral. Hence, the problem of fighting fake news is apparent.

Grade 12 social 3 (XII IPS2) class of MAN 1Kota Tangerang, where the study was conducted, consists of 40 students, forms a WhatsApp group to communicate and discuss class issues. Like other popular messaging platform, fake news and hoaxes spread freely and become a major concern because they are false and disturbing. The number of 'questionable' news shared in this WhatsApp group was 6 to 7 shares per day and considered annoying because the content sometimes dragged readers to be in state of panic. The other ones sometimes asked readers to re-share with a sense of 'threat' as well as containing links which is not reliable at all.

Woog, quoted by Funke (2017) said that one of the ways WhatsApp is trying to combat fake news is by promoting digital literacy on the platform. In addition Nolan (2017) stated that besides information literacy, teaching critical thinking in the classroom provides opportunity for students to assess fake news and critically evaluate information.

The challenge is then; (1) how critical thinking skill is embedded in daily teaching, specifically in lead in stage and (2) how students' critical thinking help them evaluate information and combat fake news. 
Ennis (1989) in Goodsett (2017) defined critical thinking as reflective and reasonable thinking that is focused on deciding what to believe or do. Critical thinking becomes importance as it enables students to use their reasoning skills to analyze and evaluate, and later on lead them to make reasonable and defensible decision about certain issues.

In addition, Willingham (2007) recommended that critical thinking should be placed in every classroom, not as an individual course but as a part of every lesson. Critical thinking can be infused in lesson by looking at things in different perspectives, reasoning with evidence and utilizing in depth questioning and solving either routines or non-routines problems.

For a classroom practice, British Council (2015) mentioned four key features of Critical Thinking and Problem Solving as follow; first, Considering Different Perspectives, second, Assessing Evidence third, Solving Non Routine Problems and four, Look for deep Structure. Considering Different Perspective is looking at an issue from multiple perspectives, to ensure that thinking is effective and avoid seeing only one side of an issue. In addition, Assessing Evidence means being open to all new evidence, even it may be contrary to one's previously held view. The feature of Solving Non Routine Problem is finding solutions to problems which are not familiar, well- rehearsed approach to allow one to practice self-directed and new thinking. Meanwhile, Looking for Deep Structure is trying to go beyond the surface structure to enable one to think effectively and understand issues more deeply.

Furthermore, Snyder \& Snyder (2008) stated that Instruction that supports critical thinking uses techniques that require students to analyze, synthesize, and evaluate information to solve problems and make decisions. For this reason, lead-in, as the first teaching step of a lesson, prepares learners to learn and establish a communicative link between them and the information about to be presented (Arendas, 1998: 240). Teachers possibly create activities that foster learners' critical thinking at the beginning of the class. When welldesigned, a good lead-in leads to successful teaching and critical thinking nurturing.

To conclude, incorporating critical thinking in daily teaching help learners distinguish fact from fiction, synthesize and evaluate information, and clearly communicate, solve problems and discover truth and therefore enables learners to combat fake news and hoaxes coming to their WhatApps. At very least, learners stop share the fake news or hoaxes with others on their social media accounts.

\section{METHOD}

The research, applying classroom action research, was carried out into a cycle of action process namely; first, planning, to develop a plan of critically informed action to improve what has been already happening, second, acting, to implement the plan, third, 
observing, to observe the effects of the action, and fourth reflecting, to reflect on results observed during the acting as a basis for further planning. It was conducted in grade XII Social 3 which consists of 40; 26 female and 14 male students. The Implementation was in semester 1 of the 2017 Academic Year, during English class, in which the learning duration was 2 teaching hours (90 minutes) per week. The time of the research was set for 3 (three) months, starting from October to December 2017.

To elicit data, this research utilized a teacher's journal and a questionnaire and an interview guide. The teacher's journal was applied to collect data regarding the process of nurturing students' critical thinking. The questionnaire was given at the end to find out students' attempt as well as their attitude toward the activities. A focus-group interview was conducted to verify data from teacher's journal and questionnaire.

\section{Activities in Cycle 1}

\section{Considering}

Different

Perspectives To lead students to the topic, they were divided into 8 groups. Each group consisted of 5 students. Each group got a piece of paper with three pictures glued on it. The tasks given were (1) study the pictures, (2) discuss with your friends in group; if the picture is a book cover, what is the title? If the picture is a movie flyer, what is the title? If the picture is an ads, what product is promoted and what is the tagline? The students worked on it in 9 minutes and after that they saw each other's work. The groups moved clockwise to visit and see others. These activities should finish in 6 minutes.

\section{Assessing Evidence}

To introduce the lesson, students, i group of four, were to identify Fact and Opinion from a cover letter. They were obliged to show the evidence of their identification from the text. After that, each group moved clockwise to another group to see others' group findings and gave comment.

\section{Solving Non Routine Problems}

As the start of the lesson, Practicing Thinking aloud by posting a newspaper headline and ask questions; (1) What does the title mean? (2) What does it remind me of, (3) What do I predict this will be about?

\section{Activities in Cycle 2}

Considering Different Perspective As a 'lead in', before reading a news item text, in the first 15 minutes, students had a look at a picture displayed on the screen. In pairs, they had to discuss about what they perceived. They took notes and shared their different ideas they had during the discussion. Students and the teacher discussed the differences.

\section{Assessing Evidence}

To begin the lesson, the students worked in pairs. They got a worksheet to work on. They were asked to evaluate a list of sources; "write 1, if it is not a reliable source, write 2 , if it might be 
credible but I'd have to check the information in another source as well and write 3 , if it is a very credible source of information". The list is as follow:

1. A journalist writing an article in a newspaper

2. Members of your own family

3. An info graphic on Facebook

4. A video by someone about the topic on YouTube

5. A published book by a qualified specialist on the subject

6. An entry on Wikipedia

7. A survey about family life in a weekly magazine

8. A documentary about family life on TV with interviews with real families

Solving Non Routine Problems

For the lesson introduction, students practiced thinking aloud questions; (1) What do I know about this topic? (2) What do I think I will learn about this topic? (3) What will I do if the content of text is beyond my expectation?.

\section{FINDINGS AND DISCUSSIONS}

\section{Cycle 1}

There are several significant findings from the teacher's note, namely; first, learners' struggle at the beginning, second, learners' dependency on their teacher and third, learners' lack of English proficiency.

When introduced to critical thinking activities, the learners seemed understood the instructions well. However, they struggled to consider various possibilities, while critical thinking required them to think of all possibilities, not just one or two. The groups came up with almost similar ideas as an effort not to make mistakes. When being confirmed, some confessed that the teacher might keep one correct answer. They 'played safe' by not really thinking of other perspectives and possibilities during the 'considering different perspectives and solving non routine problems' activities. In addition, out of forty students, about eleven students still got confused in differentiating Fact from Opinion. From the class discussion, it was comprehended that their struggle was due to their strong feeling about certain issue. They would not bother to analyse it.

The learners' dependency was significantly proved from their inconfidence in defending their answers. They held value that a teacher's viewpoints should be respected and agreed. The students seemed to get used to accept anything they were told, kept their opinion on themselves. Also, it is highlighted that few students tried to criticize the others' responses on the tasks, it turned out the groups came to a conclusion that their response on the tasks were wrong. All eyes went to the same direction, the teacher. They demanded one correct answer. When the teacher explained about considering different perspectives, they seemed confused. A correct answer was still a necessity. They counted on the teacher a lot for this one correct answer. 
One significant note which was called an attention was that their lack of proficiency in English prohibited them in becoming more expressive to respond the tasks. The evidence was when being discussed in WhatApps group in their language; some who were very rarely talked in class came up with their arguments.

Fortunately, one of the group members shared information about news related to phone number reregistration required by the government. The news sounded provocative and asked citizen not to obey it as the data will be given to certain country for criminal reason. The shared news became the topic to discuss in WhatApps group. The students, without being aware, already practiced 'considering different perspectives' and at the same time'assessing evidence' about how valid the news was in their language.

The practice was so real. At the end of the week, it was noticeable that the news share on the group decreased. The graph 1 below described the decline of the incoming threads which were shared by students in three weeks.

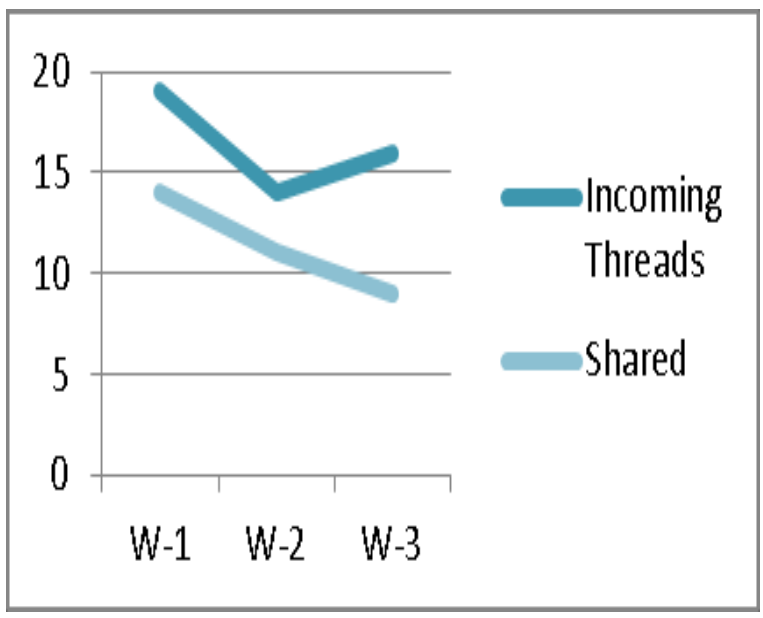

Graph 1

Number of shared thread

The trend, as shown in graph 2, also revealed that there was an increase in number of incoming threads which were not shared as the result of their critical thinking process.

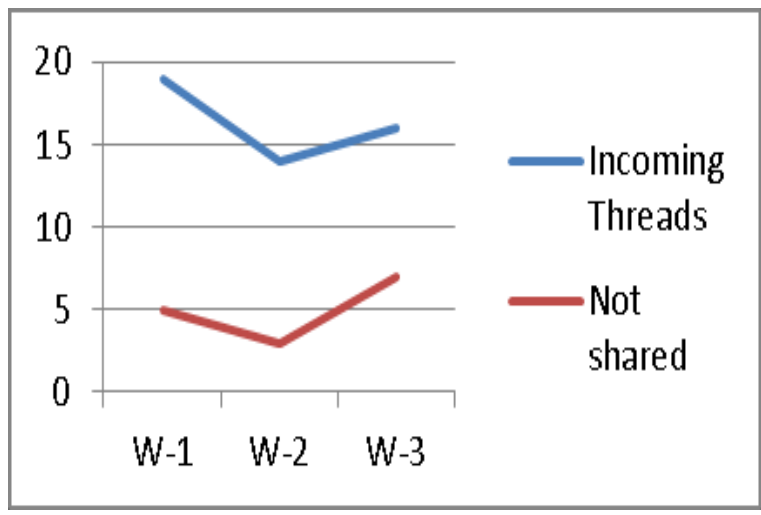

Graph 2

Number of Not shared thread

Hence, still in Whatapps group, the teacher posted a question; why were not many news share posted? What do you consider before sharing certain news? There were quite number of news share received in their personal account, they confessed, however, the students did not share the news because it had 
Volume 1 Nomor 1 Tahun 2020

nothing to do with their concern, while when it was related to their interests, they doubted if the news was trusted. In the end, the news stopped at them as they erased it.

\section{Cycle 2}

Following the students' feedback on what was experienced on the first cycle, the activities on the lead-in stage were repeated with several adjustments. Three significant adjustments were; first, the teacher slowly and carefully gave directions as well as gave enough examples, second, the groups were dynamically changed every meeting and third, the ground rules were constructed and agreed.

The ground rules helped engage student a lot with the leadin activities. They learned to appreciate others' perspectives yet felt encouraged to ask the reasons why. However, their limitation in expressing thoughts in English often led them to speak their mother tongue. The other thing to be underlined is that it was esteemed to take students' opinion into account. Teacher's supportive and positive expressions or comments on students' opinion led to their confidence in expressing their critical thinking.

The finding from questionnaire is displayed in the table below.
Table 1 Learners' Responses on the Questionnaire

\begin{tabular}{|l|c|c|c|c|}
\hline Statement & \multicolumn{2}{|c|}{$\begin{array}{c}\text { Expected } \\
\text { Responses } \\
\text { (Positive) }\end{array}$} & \multicolumn{2}{c|}{$\begin{array}{c}\text { Not expected } \\
\text { Responses } \\
\text { (Negative) }\end{array}$} \\
\cline { 2 - 5 } & $\begin{array}{l}\text { Tota } \\
\text { lly } \\
\text { Agr } \\
\text { ee }\end{array}$ & $\begin{array}{c}\text { Agr } \\
\text { ee }\end{array}$ & $\begin{array}{l}\text { Some } \\
\text { what } \\
\text { Agre } \\
\text { e }\end{array}$ & $\begin{array}{c}\text { Disa } \\
\text { gree }\end{array}$ \\
\hline $\begin{array}{l}\text { The Lead in } \\
\text { activities are } \\
\text { interesting }\end{array}$ & 23 & 17 & - & - \\
\hline $\begin{array}{l}\text { I can look at } \\
\text { issues from } \\
\text { multiple }\end{array}$ & 19 & 14 & 7 & - \\
\hline perspectives & & & & \\
\hline $\begin{array}{l}\text { I learned how } \\
\text { to gather data } \\
\text { and assess } \\
\text { evidence }\end{array}$ & 18 & 18 & 4 & - \\
\hline $\begin{array}{l}\text { I practiced } \\
\text { how to think } \\
\text { aloud }\end{array}$ & 21 & 16 & 3 & - \\
\hline $\begin{array}{l}\text { The practice } \\
\text { help me assess } \\
\text { incoming } \\
\text { threads in my } \\
\text { accounts }\end{array}$ & 28 & 12 & - & - \\
\hline
\end{tabular}

Results from questionnaire revealed students' positive response on the lead-in stage activities. The activities enabled them to look at issues from multiple perspectives as well as differentiate fact from opinion when gathering data and assessing evidence. Moreover, the activities help them practice thinking aloud including help them assess incoming thread in their instant messaging application.

The unanticipated finding was that the discussion seemed more lively in WhatApps group compared to those live in the class. Students seemed 


\section{Wawasan \\ Jurnal Balai Diklat Keagamaan Jakarta PISSN 2548-9232; EISSN ... \\ Volume 1 Nomor 1 Tahun 2020}

to be more pro active and bravely confident showing their critical thinking process.

As for the communication in WhatsApps group, it was notable that no barrier at all when communicating via this platform instant messaging service. Therefore, the teacher utilized the WhatApps group to practice critical thinking more. The teacher posted questions; 1) Why not many news shares on the group? 2) What is your consideration before you re-share certain news?

Students' responses were quite satisfying. They still received quite a number of threads, in average 20 to 25 threads a week, from various kinds of groups and other instant messaging applications. Nevertheless, as they practiced questioning how valid certain news was, they held off resharing it. A comment from a student was that she always checked and rechecked any news that she was interested in by browsing it in internet and decided whether the source was reliable.

\section{CONCLUSION}

The study affirmed that embedding activities which foster critical thinking in daily classroom practice is feasible. In addition, lead-in as the first and most basic phase in English classroom suits activities that iniatiate students' critical thinking. When they are well-designed, the activities nurturing critical thinking enabled students to assess any incoming information and help them combat fake news. In regard to the study findings, there are two main points proposed. Firstly, innovative activities that involve teachers, students, and school policy makers with critical thinking skill improvement should be encouraged. Eventually, a study assessing the effectivity of social media like WhatsApps in delivering knowledge should be conducted as well.

\section{REFERENCES}

Arendas, R, (1998). Learning to Teach (The Fourth Edition). New York: The McGrawHill Companies, Inc., 240.

British Council, (2015). Connecting Classroom: An Introduction to Core Skills for Teachers. www. britishcouncil.org.

British Council, (2015). Connecting Classroom: Teaching Critical Thinking and Problem Solving. www. britishcouncil.org.

Funke. D, (2017). Here's Why Fighting Fake News is Harder on WhatsApp than on Facebook; an article. https://www.poynter.org/news/her es-why-fightingfake-news-harder- whatsapp-facebook. Accessed on November 27, 2017.

Goodsett, M. (2017). Critical Thinking and the ACRL Framework: Fake News and Fallacies. Michael Schwartz Library Publications 144. Available 
at https://engagedscholarship.csuohio. edu/cgi/viewcontent. Accessed on November 27, 2017.

Mark. J. 2008. Teaching Critical Thinking and Problem Solving'. The Delta Pi Epsilon Journal. (L) 2, Spring/Summer.

Nolan, S. (2017). Critical Thinking and Information Fluency: Fake News in the Classroom: Opportunities for Teaching Scientific And Information Literacy, Psychology Teacher Network'. Available at: http://www.apa.org/ed/precollege/ ptn/2017/05/fake-news.aspx. ccessed on November 23, 2017.

Snyder, Lisa G. \& Snyder, Mark. J. 2008. Teaching Critical Thinking and Problem Solving'. The Delta Pi Epsilon Journal. (L) 2, Spring/Summer.

Willingham, D. 2007. Critical Thinking: Why is it Hard to Teach, American Federation of Teachers, 9-15. https://www.aft.org/sites/default/fi les/periodicals/Crit_Thinking.pdf. Accessed on Januari 5, 2018. 